\title{
Effect of zirconium additions and annealing temperature on electrical conductivity and hardness of hot rolled aluminum sheets
}

\author{
${ }^{*}$ N.A.Belov" ${ }^{1}$ A.N. Alabin', I.A.Matveeva", D.G.Eskin ${ }^{3,4}$ \\ ${ }^{1}$ Dept. of Casting Technologies, National Research and Technological University "MISIS", \\ Leninsky prosp. 4, Moscow 119049 Russia, \\ ${ }^{2}$ UC RUSAL, 13/1, Nikoloyamskaya st., Moscow 109240, Russia \\ ${ }^{3}$ Brunel University London, BCAST, Kingston Lane, Uxbridge UB8 3PH, United Kingdom \\ ${ }^{4}$ Tomsk State University, Tomsk, Prosp. Lenina 36, 634050, Russia
}

Keywords: Al-Zr alloys, $\mathrm{Al}_{3} \mathrm{Zr}$ nano-particles, phase composition, electrical conductivity, annealing temperature

\begin{abstract}
Influence of annealing cycles up to $650{ }^{\circ} \mathrm{C}$ on the specific conductivity $(\Omega)$ and hardness (HV) of hot-rolled sheets of aluminum alloys containing up to $0.5 \mathrm{wt} \% \mathrm{Zr}$ was studied. By using analytical calculations of phase composition and experimental methods (SEM, TEM, EMPA, etc.) it is demonstrated that the conductivity depends first of all on the concentration of zirconium in the aluminum solid solution which is minimum after 3-h holding at $450{ }^{\circ} \mathrm{C}$. On the other hand, the hardness of the alloy is mainly caused by the amount of nanoparticles of the $\mathrm{L}_{2}\left(\mathrm{Al}_{3} \mathrm{Zr}\right)$ phase that defines the retention of strain hardening. It is shown that the best combination of $\Omega$ and HV values can be reached within an acceptable holding time at the temperature about $450{ }^{\circ} \mathrm{C}$.
\end{abstract}

*corresponding author: nikolay-belov@yandex.ru, +7 4959511928 


\section{Introduction}

Aluminum alloys are widely used for production of wires for overhead power transmission lines where the light weight in combination with reasonable electrical conductivity makes aluminum preferable over heavy copper [1]. In recent years the power industry increased the requirements for thermally stable aluminum alloys that should combine high electrical conductivity and sufficient strength preserved after heating up to $300{ }^{\circ} \mathrm{C}$. The latter requirement rules out the use of unalloyed aluminum (AA1350) as its recrystallization-onset temperature is low (less than $250{ }^{\circ} \mathrm{C}$ ) [2]. One of the solutions of this problem is to develop low-alloyed aluminum alloys with zirconium additions [3-7], e.g. Brubak et al. [5] reported alloys with 0.5-2 wt\% Zr; Kenichi et al. [6] with 0.23-0.35 wt\% Zr and authors [7] with about 0.3 wt\% Zr. Number of widely known companies that produce wires such as Lamifil (Belgium), 3M (USA), J-Power Systems (Japan) and others, conduct research and development in the field of heat-resistant wires, where Al-Zr alloys are used International Standard IEC 62004 [8] and ASTM B941-10 [9].

Wire rods for manufacturing of electrical cables are typically manufactured by continuous casting and rolling (CCR), in particular on rolling mills "Properzi" [10] and "Southwire" [11]. The desired characteristics of Al-Zr wire (first of all, specific conductivity, strength and thermal stability) depend considerably on the processing schedule of a wire rod, which includes zirconium concentration, casting conditions, rolling regime and, especially, the heat treatment cycle.According to the experimental results of Tacer et al. [12] the conductivity of an $\mathrm{Al}-0.25 \mathrm{wt} \% \mathrm{Zr}$ alloy reaches the peak values after annealing at $450-450{ }^{\circ} \mathrm{C}$ for $60-80$ hours. Authors [13] found that the resistivity of cold-rolled sheets containing $0.3-0.6 \mathrm{wt} \% \mathrm{Zr}$ is primarily determined by the zirconium content in the aluminum solid solution.

Optimization of the process parameters is a difficult task that is caused by the complexity of CCR process (Fig.1) which significantly differs from conventional processing routes when casting of billets and subsequent deformation are separated in time and space.Positive influence of zirconium on hardness (as a measure of thermal stability) is caused by nanoparticles of the $\mathrm{L} 1_{2}$ $\left(\mathrm{Al}_{3} \mathrm{Zr}\right.$ ) phase formed in a wire rod upon decomposition of a supersaturated aluminum solid solution (further (Al)) during annealing process [14-29]. Knipling et al. [14] found that these nanoparticles start to precipitate between 350 and $375{ }^{\circ} \mathrm{C}$, achieving a peak microhardness of $420 \mathrm{MPa}$ at $425-$ $450{ }^{\circ} \mathrm{C}$. Small additions of other elements, particularly rare earth such as erbium $[21,23,28,29]$ and ytterbium [22,24,27], do not significantly affect the strengthening

The annealing process is a key which determined the objectives set out in the present paper:

a) to produce hot-rolled sheets of aluminum alloys containing up to $0.5 \mathrm{wt} \% \mathrm{Zr}$ under conditions approaching those typical of commercial CCR machines and 
b) to study the influence of annealing temperature (up to $650{ }^{\circ} \mathrm{C}$ ) on the electrical conductivity, hardness and phase composition of these alloys, in particular on the concentration of $\mathrm{Zr}$ in (Al) and the quantity of $\mathrm{L1}_{2}\left(\mathrm{Al}_{3} \mathrm{Zr}\right)$ nanoparticles.

\section{Experimental}

Sheets of experimental aluminum alloys containing between 0.1 and $0.5 \mathrm{wt} \% \mathrm{Zr}$, and wire rods of an Al-Zr alloy (0.24 wt\% Zr, $0.22 \mathrm{wt} \% \mathrm{Fe}, 0.07 \mathrm{wt} \% \mathrm{Si}$ ) were the main objects of this research. The wire rods were produced by CCRtechnology at the IrkAZ (RUSAL) smelter (Irkutsk, Russia)[30]. Experimental alloys were prepared in an electric resistance furnace in a graphite-clay crucible with an primary aluminum (99.7\% purity) as a base. Zirconium (up to $0.5 \mathrm{wt} \%$ ) was introduced into the melt in the form of an $\mathrm{Al}-15 \mathrm{wt} \% \mathrm{Zr}$ master alloy produced by Intermix Met. The additions were made at $850-900{ }^{\circ} \mathrm{C}$, i.e. above the liquidus of the alloy containing $0.5 \mathrm{wt} \% \mathrm{Zr}$, which is about $810^{\circ} \mathrm{C}[13$, 25]. Flat ingots with sizes of $40 \times 120 \times 180 \mathrm{~mm}$ (Fig. 2) were cast in a steel mold (cooling rate about $10 \mathrm{~K} / \mathrm{s}$ ). Sheets $5 \mathrm{~mm}$ thick were produced from these flat ingots according to the technological scheme shown on Fig. 3 Chemical compositions of the alloys (particularly concentration of $\mathrm{Zr}$ in the alloy $-\mathrm{C}_{\mathrm{Zr}}$ ) were determined with an emission spectrometer ARL 4460 and are given in Table 1. The sheets were annealed in a muffle electric furnace Nabetherm using step cycles in the range from 250 to $650{ }^{\circ} \mathrm{C}$ (Table 2) with an accuracy of temperature maintenance $\pm 2{ }^{\circ} \mathrm{C}$.

The specific electrical conductivity $(\Omega)$ was measured by eddy-current testing using a VE26NP device with high purity aluminum (99.99\%) as an additional standard. The Vickers hardness (HV) was determined in a Wilson Wolpert $930 \mathrm{~N}$ hardness machine (load $50 \mathrm{~N}$ ). Measurements of $\Omega$ and HV were carried out for each heat treatment cycle, making at least 5 measurements for each value. The statistical analysis of the results has been performed and the average data are reported.

The structure was examined by means of optical (OM, Axiovert 200 MMAT), transmission electron (TEM, JEM-2100), scanning electron (SEM, TESCAN VEGA 3) microscopes and by electron microprobe analysis (EMPA, OXFORD AZtec). Polished samples cut from the ingots and sheets (Fig. 2) were studied. Mechanical polishing (Struers Labopol-5) was used as well as electrolytic polishing, as these methods complement one another and enable the complete observation of the microstructure. Electrolytic polishing was performed using 12 VDC in an electrolyte containing 6 parts of ethanol, 1 part of $\mathrm{HClO}_{4}$ and 1 part of glycerin. Thin foils for transmission electron microscopy (TEM) were prepared by electrolitic thinning in a perchloric acid-alcohol solution and studied at $160 \mathrm{kV}$. 
Calculations of phase composition, particularly, mass fraction of $\mathrm{Al}_{3} \mathrm{Zr}$ phase (Q) and concentration of $\mathrm{Zr}$ in the aluminum solid solution at different temperatures $\left(\mathrm{C}_{\mathrm{Zr} \text {-(Al) }}\right)$ were made using Thermo-Calc software (version TCW-5, database TTAL5) [31].

\section{Results}

The metallographic analysis of ingots showed that the microstructures were quite similar irrespective of Zr concentration in the experimental alloys. The reason is in the complete dissolution of zirconium in the aluminum solid solution during solidification at a sufficiently high cooling rate, while the concentrations of Fe and Si do not vary much between the alloys (Table 1). The observed microstructures are typical of commercial aluminum: inclusions of $\mathrm{Al}_{8} \mathrm{Fe}_{2} \mathrm{Si}$ phase in a shape of skeletal fragments or streaks [31] at the (Al) dendritic cells boundaries (Fig. 4a). However, we observed a noticeable grain refinement with the zirconium concentration increasing. Particularly, the average linear grain size (D) in alloy 02Zr is $300 \mu \mathrm{m}$ (Fig. 4a), while in alloy 05Zr it is below $100 \mu \mathrm{m}$ (Fig. 4b). As it is well known, zirconium that is dissolved in (Al) strongly reduces electrical

conductivity [2]. Assuming that the major factor determining the electrical conductivity of experimental alloys is the content of zirconium in the aluminum solid solution $\left(\mathrm{C}_{\mathrm{Zr}-(\mathrm{Al})}\right)$, we derived

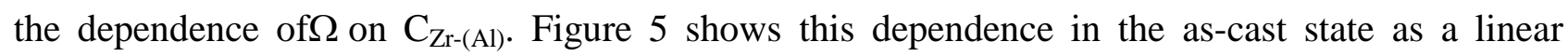
function with the coefficient $\sim 12.6$ that characterizes the decrease in $\Omega$ with the addition of 1 wt\% Zr:

$$
\Omega=35.7-12.641 \mathrm{C}_{\mathrm{Zr}-(\mathrm{Al})}
$$

The value of $\mathrm{C}_{\mathrm{Zr} \text {-(Al) }}$ was determined from experimental results. In this case we assumed that all $\mathrm{Zr}$ in the alloy is dissolved on the solid solution during solidification, hence in the as-cast state the value of $\mathrm{C}_{\mathrm{Zr} \text {-(Al) }}$ should coincide with the concentration of zirconium in the alloy $\mathrm{C}_{\mathrm{Zr}}$, as no primary intermetallics have been observed in the structure. The linear dependence shown in Fig. 5 means that the effect of grain size (see in Fig. 4 a, b) is much smaller than the effect of Zr content in the aluminum solid solution.

During rolling a fibrous structure with elongated inclusions of the Fe-containing phase are formed (Fig. 4b). The Fe:Si ratio in these particles according to EMPA is about $4-5$ (like in the $\mathrm{Al}_{8} \mathrm{Fe}_{2} \mathrm{Si}$ phase). Zirconium does not influence the structure of alloys after hot rolling, as can be revealed in a light microscope.

According to the Al-Zr phase diagram almost all experimental alloys (disregarding Fe and Si impurities) fall in the solid state into the two-phase region ( $\mathrm{Al})+\mathrm{Al}_{3} \mathrm{Zr}$ (Fig. 6). Alloys $02 \mathrm{Zr}$ and 
03Zr that are single-phased at $650^{\circ} \mathrm{C}$ make an exception. The alloy 02Zr falls into the single-phase area also at $600{ }^{\circ} \mathrm{C}$. From Fig. 6 it follows that annealing of all the studied alloys should result in decomposition of the supersaturated $(\mathrm{Al})$ and formation of $\mathrm{Al}_{3} \mathrm{Zr}$ phase precipitations.

Dependences of electrical conductivity of the experimental alloys on the temperature at the last step of annealing have complex character (Fig. 7a). Unlike unalloyed aluminum where the value of $\Omega$ changes only slightly (the scatter of data is comparable with the experimental accuracy), the alloys with zirconium demonstrate significant changes. The changes are especially great at the maximum concentration of zirconium in the alloy $\left(\mathrm{C}_{\mathrm{Zr}}\right)$, i.e. the difference in $\Omega$ values in alloy $5 \mathrm{Zr}$ across the range of annealing temperatures is $5.4 \times 10^{-9} \mathrm{Ohm} \mathrm{m}$ (or $\sim 15 \%$ ). The annealing up to $350{ }^{\circ} \mathrm{C}$ leads to slight increase in electrical conductivity, with the differences between alloys remaining. Value of $\Omega$ reaches maximum after annealing on the T450 cycle. It should be noted that in this state the difference in electrical conductivity between $\mathrm{Zr}$-containing alloys is minimal. Further increasing temperature leads to the decreasing $\Omega$, the difference between alloys becomes greater again but to a lesser extent as compared to the as-cast state.

The dependences of hardness on the temperature at the last step of annealing (Fig. 7b) show that work hardening of all $\mathrm{Zr}$-containing alloys remains up to $300{ }^{\circ} \mathrm{C}$ inclusive. It should be noted that unalloyed aluminum at this temperature completely softens and its hardness does not exceed 20 $\mathrm{HV}$. As the temperature increases the influence of $\mathrm{C}_{\mathrm{Zr}}$ on the hardness $\mathrm{HV}$ becomes essential. In the alloys $02 \mathrm{Zr}$ and $03 \mathrm{Zr}$ the noticeable softening is observed at $350{ }^{\circ} \mathrm{C}$ and $400{ }^{\circ} \mathrm{C}$, respectively. In more concentrated alloys $04 \mathrm{Zr}$ and $05 \mathrm{Zr}$ the hardness remains at a rather high level up to $450{ }^{\circ} \mathrm{C}$. At $500{ }^{\circ} \mathrm{C}$ and higher all alloys strongly soften and the difference between them is leveled.

The metallographic analysis of the annealed sheets shows that that the formation of recrystallized grains coincides with the softening; while the higher values of hardness - with the preservation of fibrous, worked structure (Fig. 8). The resistance to recrystallization is caused by the formation of nanoparticles of the $\mathrm{Al}_{3} \mathrm{Zr}$ phase as revealed in TEM images. As Fig. 9 shows, the average size of these particles does not exceed $10 \mathrm{~nm}$ at annealing cycles up to T450. Upon heating over $450{ }^{\circ} \mathrm{C}$ particles coarsen and then transform to the stable $\mathrm{D}_{23} \mathrm{Al}_{3} \mathrm{Zr}$ phase which can be seen in an SEM image. For example, precipitates of the stable phase in alloy 05Zr reach $1 \mu \mathrm{m}$ in size after annealing in the T650 cycle (Fig. 10a). In alloys 02Zr and 03Zr annealed at this cycle, these particles are absent due to the complete dissolution of $\mathrm{Zr}$ in (Al) in full compliance with the $\mathrm{Al}-\mathrm{Zr}$ phase diagram (Fig. 6). Needle-shaped particles (Fig. 10b) contain iron but not silicon, as revealed by SEM-EPMA. It may be explained by phase transformation (during annealing at $650{ }^{0} \mathrm{C}$ ) according the equilibrium $\mathrm{Al}-\mathrm{Fe}-\mathrm{Si}$ phase diagram [32,33].

The industrial relevance of the obtained results was verified using an industrially produced wire rod containing $0.24 \% \mathrm{Zr}$. CCR equipment (at the IrkAZ ) doesno allow the melt temperature 
near cooling wheel (Fig. 1) to be above $\sim 750^{\circ} \mathrm{C}$ so it prevents the use of Al-Zr alloys with a higher Zr content. Multistage (T2) and one-stage (T1) cycles were considered. The first were conducted similarly to experimental alloys, i.e. with 3-hour holding at each step (see Table 2), one-stage annealing was carried out at 300, 350, 400, 450 and $500{ }^{\circ} \mathrm{C}$ with 10-hour holding. Apparently from Fig. 11, in both cases the maximum value of conductivity is observed at $450{ }^{\circ} \mathrm{C}$. At the same time, the multistep annealing slightly increases $\Omega$ in comparison with the one-step heating (35.4 against 35.1 $\mathrm{MS} \mathrm{m}^{-1}$ ). In the case of lower temperatures the required holding time significantly increases, whereas at higher temperatures the conductivity decreases due the increased solubility of $\mathrm{Zr}$ in (Al).

\section{Discussion}

Structural and phase transformations during annealing process were estimated through conductivity and hardness change (Fig.7) and also by the results of calculation. Quantitative values characterizing the phase composition at specific temperatures are given in Table 3. Calculations were carried out for both stable and metastable equilibrium according to weather $\mathrm{D}_{23}$ or $\mathrm{L} 1_{2}$ phases are formed, respectively [19]. From Table 3 it is evident that the solubility of $\mathrm{Zr}$ in (Al) considerably increases at temperatures over $400-450{ }^{\circ} \mathrm{C}$. Moreover, in the case of the metastable equilibrium the solubility is significantly higher.

As it follows from the dependences shown on Fig. 7a, when using multistage annealing the maximum values of electrical conductivity are reached at $450{ }^{\circ} \mathrm{C}$ which possibly correlates with the maximum depletion of the aluminum solid solution in Zr. However, it does not correlate with the calculated data for the metastable equilibrium showing that $\mathrm{C}_{\mathrm{Zr}-(\mathrm{Al})}$ at the given temperature is considerable (Table 3).

For an explanation of the dependences shown on Fig.7, the concentration of zirconium in (Al) was inverse-calculated using the coefficient of linear correlation between $\mathrm{C}_{\mathrm{Zr} \text {-(Al) }}$ and $\Omega$ (Fig. 4) and experimentally determined values of $\Omega$ (in sheets). Thus other factors (in particular, number of $\mathrm{Al}_{3} \mathrm{Zr}$ precipitates and their size) were neglected. The results of the calculation given in Table 4 show that in $\mathrm{T} 350$ state the calculated values of $\mathrm{C}_{\mathrm{Zr} \text {-(Al) }}$ are significantly higher than those shown in Table 4. Hence, it follows that 3-hour annealing at $350{ }^{\circ} \mathrm{C}$ is obviously insufficient for achieving the equilibrium (in this case - metastable). On the other hand, in T450 state the calculated values of $\mathrm{C}_{\mathrm{Zr} \text {-(Al) }}$ are higher than the solubility of $\mathrm{Zr}$ in (Al) according to the stable $\mathrm{Al}-\mathrm{Zr}$ phase diagram, but are much lower than for the metastable equilibrium. As the precipitates of the $\mathrm{L} 1_{2}$ phase are experimentally revealed in this condition(Fig. 9), it may be assumed that calculations according to

TTAL5 base give higher values of $\mathrm{C}_{\mathrm{Zr} \text {-(Al) }}$ for the metastable option (“overestimate”).According Sigli [34] the metastable solubilty of $\mathrm{Zr}$ in (Al) at $450{ }^{\circ} \mathrm{C}$ is about $0.1 \mathrm{wt} \%$ (twice as less as shown in 
Table 4). In T550 state the calculated values of $\mathrm{C}_{\mathrm{Zr}-(\mathrm{Al})}$ correspond well to the stable phase diagram $\mathrm{Al}-\mathrm{Zr}$ that allows us to assume formation of the $\mathrm{D}_{23}$ phase instead of $\mathrm{L} 1_{2}$. The mass fraction (Q) of secondary precipitates of the $\mathrm{Al}_{3} \mathrm{Zr}$ phase were calculated using the difference between $\mathrm{C}_{\mathrm{Zr}}$ and $\mathrm{C}_{\mathrm{Zr}}$ (Al), as well as the concentration of $\mathrm{Zr}$ in this phase (53 wt\%). As Table 4 shows, the quantity of $\mathrm{L} 1_{2}$ precipitates is maximum in the $05 \mathrm{Zr}$ alloy in T450 state, when the best combination between hardness and electrical conductivity is reached. On the other hand, in 02Zr alloy the T350 state is most optimal when $\mathrm{C}_{\mathrm{Zr} \text {-(Al) }}$ value is minimum and $\mathrm{Q}$, on the contrary, is maximum. As after annealing at the T550 cycle all alloys possess low hardness, it may be considered that the number of $\mathrm{D}_{23}$ precipitates does not significantly affect the hardness at $550{ }^{\circ} \mathrm{C}$ (and, obviously, at higher temperatures).

The results of the calculations given above, allow us to explain the influence of zirconium $\left(\mathrm{C}_{\mathrm{Zr}}\right)$ on the conductivity and hardness after the specific cycles of annealing (Fig.12). In the initial state the dependence between $\Omega$ and $\mathrm{C}_{\mathrm{Zr}}$ is close to linear (with a small deviation towards decrease at the increased $\mathrm{C}_{\mathrm{Zr}}$ values (Fig.12a)). It can be explained that during hot rolling, zirconium generally remains in (Al) and only in alloys 04Zr and 05Zr there is a chance of some decomposition (see Table 4). Dependence $\Omega-\mathrm{C}_{\mathrm{Zr}}$ for T350 state is similar to the initial state, but values of $\Omega$ are higher by approximately $1.5-2 \mathrm{Ohm} \cdot \mathrm{m} \cdot 10^{-9}$, that indicates the partial precipitation of $\mathrm{Zr}$ from (Al). The most interesting pattern is observed in T450 state where the value of $\Omega$ does not significantly depend on $\mathrm{C}_{\mathrm{Zr}}$. This suggests that the influence of secondary precipitates of $\mathrm{Al}_{3} \mathrm{Zr}\left(\mathrm{L} 1_{2}\right)$ on $\Omega$ is insignificant (unlike $\mathrm{C}_{\mathrm{Zr}-(\mathrm{Al})}$ ) as compared with the influence of $\mathrm{Zr}$ content in (Al) (see Fig. 5). As a result the experimental alloys in T450 state differ only by a number of $\mathrm{Al}_{3} \mathrm{Zr}$ precipitates (see Table 4). After annealing on T550 cycle the difference between the alloys is also insignificant that can be explained by close values of $\mathrm{C}_{\mathrm{Zr} \text {-(Al) }}$. The dependences of hardness on $\mathrm{C}_{\mathrm{Zr}}$ (Fig.12b) can be explained by the quantity of $\mathrm{L}_{2}\left(\mathrm{Al}_{3} \mathrm{Zr}\right)$ nanoparticles (Fig.9) that define strain hardness retention. The influence of $\mathrm{C}_{\mathrm{Zr}}$ is most considerably pronounced after annealing on the T450 cycle when the amount of the $\mathrm{L}_{2}$ phase in all alloys (except 02Zr) is maximum.

From the point of view of obtaining the highest conductivity the entire zirconium has to be bound into the $\mathrm{Al}_{3} \mathrm{Zr}$ phase, and for this purpose the annealing temperature has to be the lowest possible as this corresponds to the minimum equilibrium values of $\mathrm{C}_{\mathrm{Zr} \text {-(Al) }}$ (Table 3). However, because of the slow diffusion of $\mathrm{Zr}$ in (Al) at temperatures 300 to $350{ }^{\circ} \mathrm{C}$, the required time for dissolution is too long [14]. It is obvious that this way is unacceptable for practical applications. Besides, it is necessary to take into account that heat-resistant alloys should be subjected to stabilizing heat treatment at a temperature exceeding the maximum working temperature. From the obtained experimental data and results of calculation it may be concluded that the combination of conductivity and hardness (which has close correlation with strength properties) can be achieved if 
the temperature of heat treatment is in the range 400 to $450{ }^{\circ} \mathrm{C}$, and the concentration of zirconium is $0.3 \%$ and higher (see in Fig. 7, alloys 03Zr, 04Zr, and 05Zr).

\section{Summary}

1. Influence of annealing cycles up to $650{ }^{\circ} \mathrm{C}$ on the specific conductivity and hardness of hotrolled sheets of aluminum alloys containing up to $0.5 \mathrm{wt} \% \mathrm{Zr}$ was studied for the conditions approaching those realized at industrial continuous casting and rolling units.

2. By using analytical calculations and experimental methods it is demonstrated that the conductivity depends first of all on the concentration of zirconium in the aluminum solid solution which is minimum after 3-h holding at $450{ }^{\circ} \mathrm{C}$. On the other hand, the hardness of the alloy is mainly caused by the amount of nanoparticles of the $\mathrm{L}_{2}\left(\mathrm{Al}_{3} \mathrm{Zr}\right)$ phase that defines the retention of strain hardening.

3. It is shown that the best combination of conductivity, strength and hardnessvalues can be reached within an acceptable holding time at the temperature about $450{ }^{\circ} \mathrm{C}$. At lower temperatures the necessary holding time significantly increases, whereas at higher temperatures there is a decrease in conductivity that is related to a greater solubility of $\mathrm{Zr}$ in ( $\mathrm{Al})$.

\section{Acknowledgment}

This work was financially supported by the Ministry of Education and Science of the Russian Federation (Contract No 14.578.21.0004, unique ID of Project - RMEF157814X0004). 


\section{References}

[1] POLMEAR I J. Light Metals: From Traditional Alloys to Nanocrystals [M]. 4th ed. Burlington: Elsevier, 2006.

[2] HATCH J E. Aluminum: Properties and Physical Metallurgy [M]. Ohio: ASM, 1984.

[3] KNYCH T, JABŁONSKI M, SMYRAK B. New aluminium alloys for electrical wires of fine diameter for automotive industry [J]. Archives of Metallurgy and Materials, 2009, 54: 671-676. [4] ZHOU W W, CAI B, LI W J, LIU Z X, YANG S. Heat-resistant Al-0.2Sc-0.04Zr electrical conductor [J]. Materials Science and Engineering: A, 2012, 552: 353-358.

[5] BRUBAK J P, EFTESTOL B, LADISZLAIDESZ F. Aluminium alloy, a method of making it and an application of the alloy: US Patent, 5067994 [P]. 1991-11-26.

[6] KENICHI S, KAZUHISA Y, YASUMASA H,TAKASI K, MINORU Y. High conductive heat-resistant aluminum alloy: US Patent, 4402763 [P]. 1983-09-06.

[7] BELOV N A, ALABIN A N, TOLEUOVA A. Comparative analysis of alloying additives as applied to the production of heat-resistant wires [J]. Metal Science and Heat Treatment, 2011, 53: 455-459.

[8] IEC 62004-2007 [S]. International Standard, 2007.

[9] B941-10 [S]. ASTM Standard, 2010.

[10] Continuous casting and rolling (on rolling mills "Properzi”) [EB/OL]. Information on http://www.properzi.com.

[11] Continuous casting and rolling (on rolling mills “Southwire”) [EB/OL]. Information on http://www.southwire.com.

[12] TECER H, ACER E, EROL H, GÜNDÜZ M. Effect of aging on conductivity of heat resistant overhead line conductors [J]. Materials Science Forum, 2013, 765: 783-787.

[13] BELOV N A, ALABIN A N, PROKHOROV A YU. The influence that a zirconium additive has on the strength and electrical resistance of cold-rolled aluminum sheets [J]. Russian Journal of Non-Ferrous Metals, 2009, Vol. 50, No. 4, pp. 357-362

[14] KNIPLING K E, KARNESKY R A, LEE C P, DUNAND D C, SEIDMAN D N. Precipitation evolution in $\mathrm{Al}-0.1 \mathrm{Sc}, \mathrm{Al}-0.1 \mathrm{Zr}$ and $\mathrm{Al}-0.1 \mathrm{Sc}-0.1 \mathrm{Zr}$ (at.\%) alloys during isochronal ageing [J]. Acta Materialia, 2010, 58: 5184-5195.

[15] CLOUET E, BARBU A, LAE L, MARTIN G. Precipitation kinetics of $\mathrm{Al}_{3} \mathrm{Zr}$ and $\mathrm{Al}_{3} \mathrm{Sc}$ in aluminum alloys modeled with cluster dynamics [J]. Acta Materialia, 2005, 53: 2313-2325.

[16] DESCHAMP A, GUYO P. In situ small-angle scattering study of the precipitation kinetics in an Al-Zr-Sc alloy [J]. Acta Materialia, 2007, 55: 2775-2783. 
[17] LEFEBVRE W, DANOIX F, HALLEM H, FORBORD B, BOSTEL A, MARTHINSEN K. Precipitation kinetic of $\mathrm{Al}_{3}(\mathrm{Sc}, \mathrm{Zr})$ dispersoids in aluminium [J]. Journal of Alloys and Compounds, 2009, 470: 107-110.

[18] FORBORD B, LEFEBVRE W, DANOIX F, HALLEM H, MARTHINSEN K. Three dimensional atom probe investigation on the formation of $\mathrm{Al}_{3}(\mathrm{Sc}, \mathrm{Zr})$-dispersoids in aluminium alloys [J]. Scripta Materialia, 2004, 51: 333-337.

[19] KNIPLING K E, DUNAND D C, SEIDMAN D N. Precipitation evolution in Al-Zr and Al$\mathrm{Zr}-\mathrm{Ti}$ alloys during aging at $450-600^{\circ} \mathrm{C}$ [J]. Acta Materialia, 2008, 56: 1182-1195.

[20] BOOTH-MORRISON C, MAO Z, DIAZ M, DUNAND D C, WOLVERTON C, SEIDMAN D N. Role of silicon in accelerating the nucleation of $\mathrm{Al}_{3}(\mathrm{Sc}, \mathrm{Zr})$ precipitates in dilute Al-Sc-Zr alloys [J]. Acta Materialia, 2012, 60: 4740-4752.

[21] BOOTH-MORRISON C, SEIDMAN D N, DUNAND D C. Effect of Er additions on ambient and high-temperature strength of precipitation-strengthened $\mathrm{Al}-\mathrm{Zr}-\mathrm{Sc}-\mathrm{Si}$ alloys [J]. Acta Materialia, 2012, 60: 3643-3654.

[22] VAN DALEN M E, GYGER T, DUNAND D C, SEIDMAN D N. Effects of Yb and Zr microalloying additions on the microstructure and mechanical properties of dilute Al-Sc alloys [J]. Acta Materialia, 2011, 59: 7615-7626.

[23] BOOTH-MORRISON C, DUNAND D C, SEIDMAN D N. Coarsening resistance at $400{ }^{\circ} \mathrm{C}$ of precipitation-strengthened Al-Zr-Sc-Er alloys [J]. Acta Materialia, 2011, 59: 7029-7042.

[24] PENG G, CHEN K, FANG H, CHEN S. A study of nanoscale $\mathrm{Al}_{3}(\mathrm{Zr}, \mathrm{Yb})$ dispersoids structure and thermal stability in Al-Zr-Yb alloy [J]. Materials Science and Engineering A, 2012, 535: 311- 315.

[25] BELOV N A, ALABIN A N, ESKIN D G, ISTOMIN-KASTROVSKIY V V. Optimization of Hardening of Al-Zr-Sc Casting Alloys [J]. Journal of Materials Science, 2006, 41: 5890-5899.

[26] FORBORD B, LEFEBRE W, DANOIX F, HALLEM H, MARTHINSEN K. Three dimensional atom probe investigation on the formation of $\mathrm{Al}_{3}(\mathrm{Sc}, \mathrm{Zr})$-dispersoids in aluminium alloys [J]. Scripta Materialia, 2004, 51: 333-337.

[27] PENG G., CHEN K., FANG H., CHEN S. A study of nanoscale $\mathrm{Al}_{3}(\mathrm{Zr}, \mathrm{Yb})$ dispersoids structure and thermal stability in Al-Zr-Yb alloy [J]. Materials Science and Engineering A, 2012, 535: 311- 315.

[28] WEN S P, GAO K Y, HUANG H, WANG W, NIE Z R. Precipitation evolution in Al-Er-Zr alloys during aging at elevated temperature [J]. Journal of Alloys and Compounds, 2013, 574: 9297.

[29] LI H, GAO Z, YIN H, JIANG H, SUA X, BINA J. Effects of Er and Zr additions on precipitation and recrystallization of pure aluminum [J]. Scripta Materialia, 2013, 68: 59-62. 
[30] IrkAZ (RUSAL) [EB/OL]. Information on http://www.rusal.ru.

[31] Databases released by Thermo-Calc Software Company [EB/OL]. Information on http://www.thermocalc.com.

[32] BELOV N A, AKSENOV A A, ESKIN D G. Multicomponent Phase Diagrams: Applications for Commercial Aluminum Alloys [M]. Kidlington: Elsevier, 2005.

[33] CHEN H, CHEN Q, DU Y, BRATBERG J, ENGSTRÖM A. Update of Al-Fe-Si, $\mathrm{Al}-\mathrm{Mn}-\mathrm{Si}$ and $\mathrm{Al}-\mathrm{Fe}-\mathrm{Mn}-\mathrm{Si}$ thermodynamic descriptions [J]. Transactions of Nonferrous Metals Society of China, 2014, 24: 2041-2053.

[34] SIGLI C. Zirconium Solubility in Aluminum Alloys [C]//Proc International Conference on Aluminium Alloys 2004. Brisbane, Australia: ICAA9, 2004: 1353-1358. 


\section{List of Figures}

Figure 1: Main technological stages of Al-Zrwire production

Figure 2: Experimental ingots (a) and sheets (b) of Al-Zr alloys

Figure 3: Temperature-technological scheme of experimental sheets production

Figure 4: Microstructures of alloys Al-0.48\% Zr (a, c, d) and Al-0.18\% Zr (b):

(a, b, c) as-cast ingots; (d) hot rolled sheet, (a, b) OM, (c, d) SEM

Figure 5: Electrical conductivity versus $\mathrm{Zr}$ content in as-cast ingot

Figure 6: Phase diagram Al-Zr:

positions of experimental alloys at annealing temperatures are shown

Figure 7: Electrical conductivity (a) and hardness of Al-Zr alloys versus temperature (of last step of annealing)

Figure 8: Grain structure of Al-Zr sheets after annealing, SEM (EBSD)

Figure 9: TEM structure of Al-0.48\%Zr alloy after annealing T450 (see in Table 2)

Figure 10:SEM structure of Al-0.48\%Zr alloy after annealing T650 (see in Table 2)

a) coarsened $\mathrm{Al}_{3} \mathrm{Zr}$ precipitates (points 14,15, and 16), b) $\mathrm{Al}_{3} \mathrm{Fe}$ needle-like particles

Figure 11: Effect of annealing temperature on electrical conductivity of wire rod $(0.24 \% \mathrm{Zr})$ :

T1 - one-stage annealing, T2 - multistage annealing

Figure 12: Electrical conductivity (a) and hardness (b) of Al-Zr sheet alloys versus $\mathrm{Zr}$ content

\section{List of Tables}

Table 1. Chemical composition of experimental alloys

Table 2. Annealing regimes of $\mathrm{Al}-\mathrm{Zr}$ sheets

Table 3. Calculated values of $\mathrm{C}_{1}$ and $\mathrm{Q}$ for experimental alloys at various temperutures

Table 4. Calculated values of $\mathrm{Zr}$ solubility in aluminum solid solution $\left(\mathrm{C}_{\mathrm{Zr}-(\mathrm{Al})}\right)$ and mass fractions of $\mathrm{Al}_{3} \mathrm{Zr}$ phase $(\mathrm{Q})$ in experimental alloys ${ }^{1}$ after annealing ${ }^{2}$ 
Table 1. Chemical composition of experimental alloys

\begin{tabular}{lllll}
\hline Alloy & \multicolumn{2}{l}{ Concentration, wt\% (at. \%) } \\
\cline { 2 - 5 } & $\mathrm{Si}$ & Fe & $\mathrm{Zr}$ & $\mathrm{Al}$ \\
\hline $00 \mathrm{Zr}$ & $0.073(0.070)$ & $0.140(0.068)$ & - & Base \\
$02 \mathrm{Zr}$ & $0.072(0.069)$ & $0.139(0.067)$ & $0.180(0.053)$ & Base \\
$03 \mathrm{Zr}$ & $0.074(0.071)$ & $0.131(0.064)$ & $0.283(0.084)$ & Base \\
$04 \mathrm{Zr}$ & $0.080(0.077)$ & $0.140(0.068)$ & $0.380(0.113)$ & Base \\
$05 \mathrm{Zr}$ & $0.075(0.072)$ & $0.133(0.065)$ & $0.476(0.141)$ & Base \\
\hline
\end{tabular}


Table 2. Annealing regimes of $\mathrm{Al}-\mathrm{Zr}$ sheets

\begin{tabular}{ll}
\hline Designation & Annealing regime \\
\hline T300 & T300 ${ }^{\circ} \mathrm{C}, 3$ hours \\
T350 & T300 $+350{ }^{\circ} \mathrm{C}, 3$ hours \\
T400 & $\mathrm{T} 350+400{ }^{\circ} \mathrm{C}, 3$ hours \\
T450 & $\mathrm{T} 400+450{ }^{\circ} \mathrm{C}, 3$ hours \\
T500 & $\mathrm{T} 450+500^{\circ} \mathrm{C}, 3$ hours \\
T550 & $\mathrm{T} 500+550^{\circ} \mathrm{C}, 3$ hours \\
T600 & $\mathrm{T} 550+600{ }^{\circ} \mathrm{C}, 3$ hours \\
T650 & $\mathrm{T} 600+650{ }^{\circ} \mathrm{C}, 3$ hours \\
\hline
\end{tabular}


Table 3. Calculated values of $\mathrm{C}_{\mathrm{Zr}-(\mathrm{Al})}$ and $\mathrm{Q}$ for experimental alloys at various temperatures

\begin{tabular}{|c|c|c|c|c|c|}
\hline \multirow[t]{2}{*}{ Alloy $^{1}$} & \multirow[t]{2}{*}{ Temperature $\left({ }^{\circ} \mathrm{C}\right)$} & \multicolumn{2}{|c|}{ Stable phase equilibria $\left(\mathrm{DO}_{23}\right)$} & \multicolumn{2}{|c|}{ Metastable phase equilibria (L12) } \\
\hline & & $\mathrm{C}_{\mathrm{Zr}-(\mathrm{Al})}{ }^{2}(\mathrm{wt} \%)$ & $\mathrm{Q}^{3}(\mathrm{wt} \%)$ & $\mathrm{C}_{\mathrm{Zr}-(\mathrm{Al})}{ }^{2}(\mathrm{wt} \%)$ & $\mathrm{Q}^{3}(\mathrm{wt} \%)$ \\
\hline \multirow[t]{8}{*}{ 02Zr } & 300 & 0.003 & 0.33 & 0.037 & 0.27 \\
\hline & 350 & 0.009 & 0.32 & 0.072 & 0.20 \\
\hline & 400 & 0.019 & 0.30 & 0.125 & 0.10 \\
\hline & 450 & 0.038 & 0.27 & 0.180 & 0 \\
\hline & 500 & 0.068 & 0.21 & 0.180 & 0 \\
\hline & 550 & 0.113 & 0.13 & 0.180 & 0 \\
\hline & 600 & 0.178 & $<0.01$ & 0.180 & 0 \\
\hline & 650 & 0.180 & 0 & 0.180 & 0 \\
\hline \multirow{8}{*}{ 03Zr } & 300 & 0.003 & 0.52 & 0.037 & 0.46 \\
\hline & 350 & 0.009 & 0.51 & 0.072 & 0.39 \\
\hline & 400 & 0.019 & 0.49 & 0.125 & 0.29 \\
\hline & 450 & 0.038 & 0.46 & 0.203 & 0.14 \\
\hline & 500 & 0.068 & 0.40 & 0.283 & 0 \\
\hline & 550 & 0.113 & 0.32 & 0.283 & 0 \\
\hline & 600 & 0.178 & 0.19 & 0.283 & 0 \\
\hline & 650 & 0.267 & 0.02 & 0.283 & 0 \\
\hline \multirow[t]{8}{*}{$04 \mathrm{Zr}$} & 300 & 0.003 & 0.71 & 0.037 & 0.65 \\
\hline & 350 & 0.009 & 0.70 & 0.072 & 0.58 \\
\hline & 400 & 0.019 & 0.68 & 0.125 & 0.48 \\
\hline & 450 & 0.038 & 0.65 & 0.203 & 0.33 \\
\hline & 500 & 0.068 & 0.59 & 0.309 & 0.14 \\
\hline & 550 & 0.113 & 0.51 & 0.380 & 0 \\
\hline & 600 & 0.178 & 0.38 & 0.380 & 0 \\
\hline & 650 & 0.267 & 0.21 & 0.380 & 0 \\
\hline \multirow[t]{8}{*}{$05 \mathrm{Zr}$} & 300 & 0.003 & 0.90 & 0.037 & 0.83 \\
\hline & 350 & 0.009 & 0.89 & 0.072 & 0.76 \\
\hline & 400 & 0.019 & 0.87 & 0.125 & 0.66 \\
\hline & 450 & 0.038 & 0.84 & 0.203 & 0.51 \\
\hline & 500 & 0.068 & 0.78 & 0.309 & 0.31 \\
\hline & 550 & 0.113 & 0.69 & 0.449 & 0.05 \\
\hline & 600 & 0.178 & 0.57 & 0.476 & 0 \\
\hline & 650 & 0.267 & 0.40 & 0.476 & 0 \\
\hline
\end{tabular}

${ }^{1}$ see in Table $1,{ }^{2}$ concentration $\mathrm{Zr}$ in $(\mathrm{Al}),{ }^{3}$ volume fraction of $\mathrm{Al}_{3} \mathrm{Zr}$ 
Table 4. Calculated values of $\mathrm{Zr}$ solubility in aluminum solid solution $\left(\mathrm{C}_{\mathrm{Zr}-(\mathrm{Al})}\right)$ and mass fractions of $\mathrm{Al}_{3} \mathrm{Zr}$ phase (Q) in experimental alloys ${ }^{1}$ after annealing ${ }^{2}$

\begin{tabular}{lllllll}
\hline Alloy & \multicolumn{7}{l}{ C Zr-(Al) $(\mathrm{wt} \%)$} & $\mathrm{Q}(\mathrm{wt} \%)$ \\
\cline { 2 - 7 } & $\mathrm{T} 350$ & $\mathrm{~T} 450$ & $\mathrm{~T} 550$ & $\mathrm{~T} 350$ & $\mathrm{~T} 450$ & $\mathrm{~T} 550$ \\
\cline { 2 - 7 } $02 \mathrm{Zr}$ & 0.060 & 0.079 & 0.106 & 0.226 & 0.191 & 0.140 \\
$03 \mathrm{Zr}$ & 0.185 & 0.085 & 0.099 & 0.185 & 0.374 & 0.347 \\
$04 \mathrm{Zr}$ & 0.232 & 0.066 & 0.099 & 0.279 & 0.592 & 0.530 \\
$05 Z r$ & 0.285 & 0.073 & 0.099 & 0.360 & 0.760 & 0.711 \\
\hline
\end{tabular}

${ }^{1}$ see in Table $1,{ }^{2}$ see in Table 2 


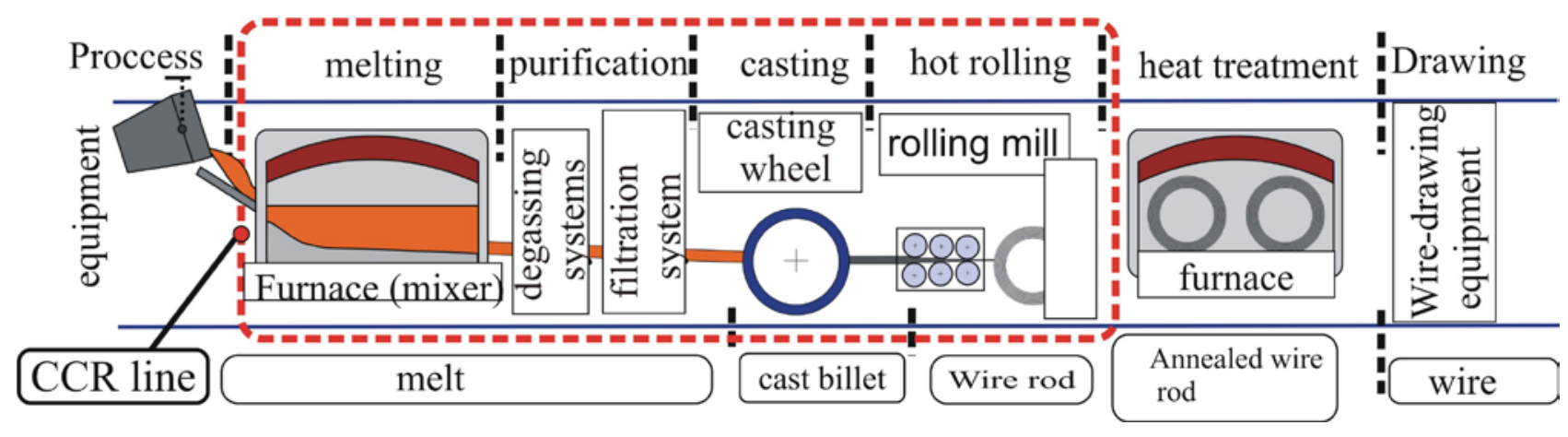

Fig. 1

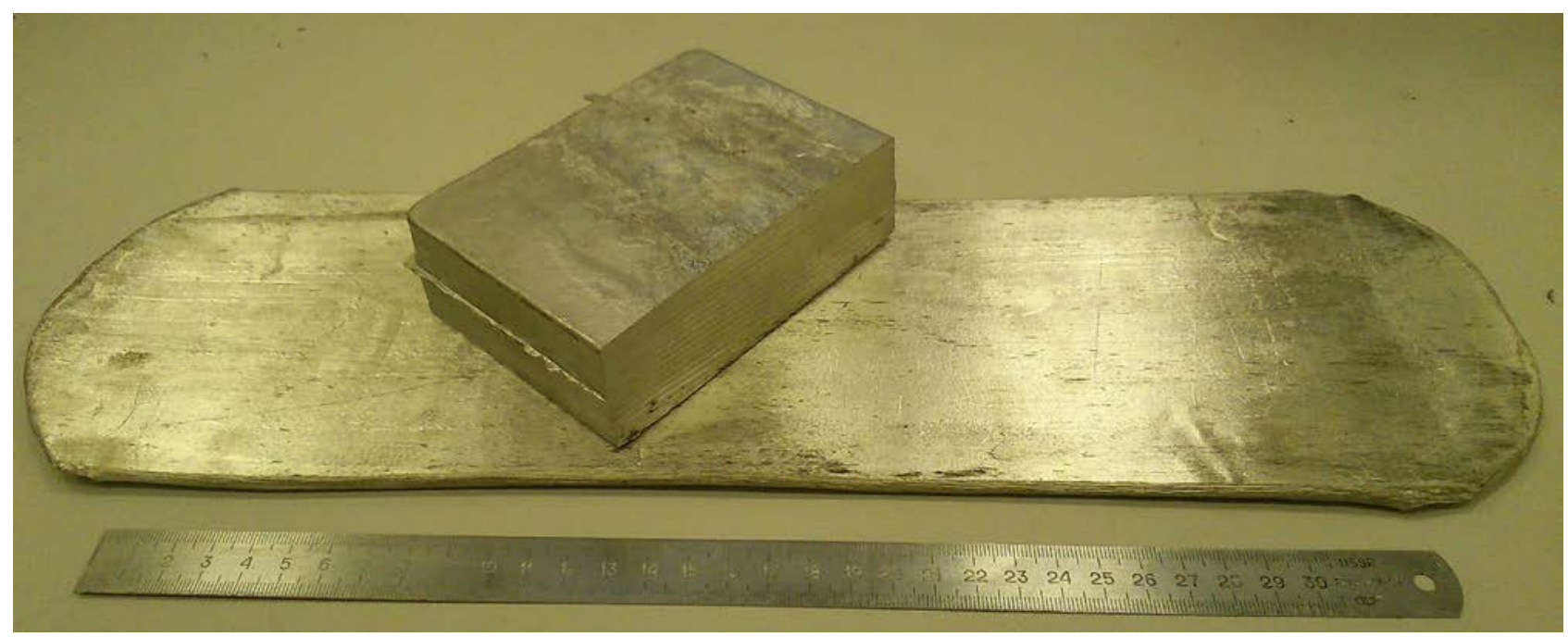

Fig. 2

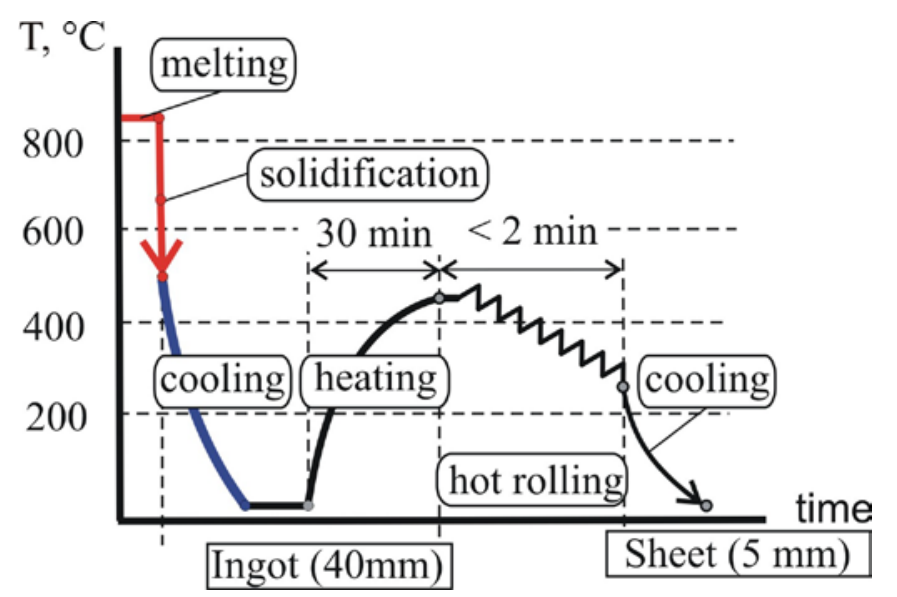

Fig. 3 

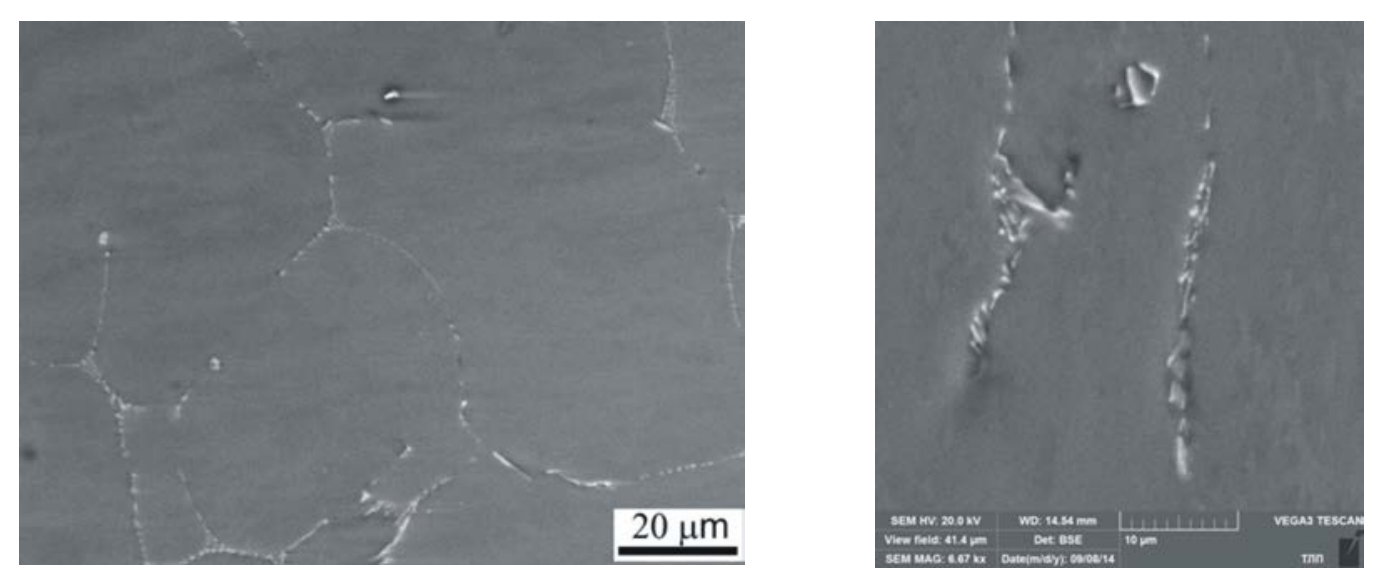

Fig. 4

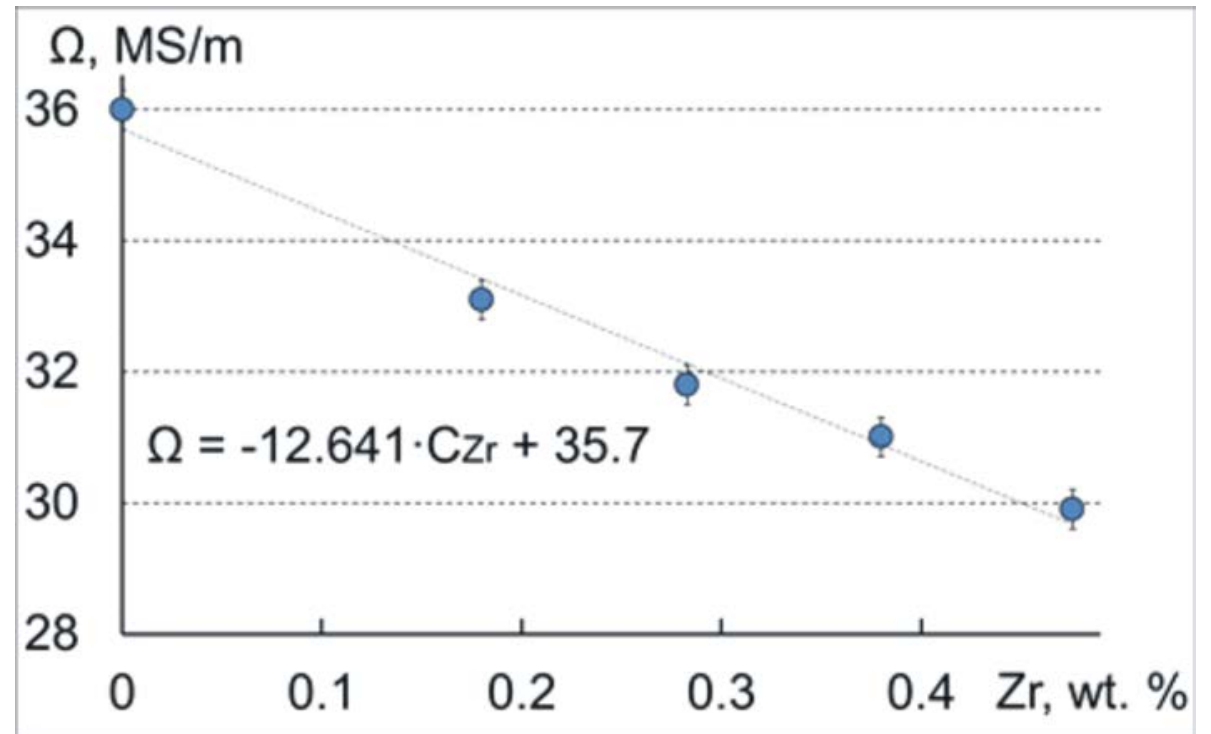

Fig. 5

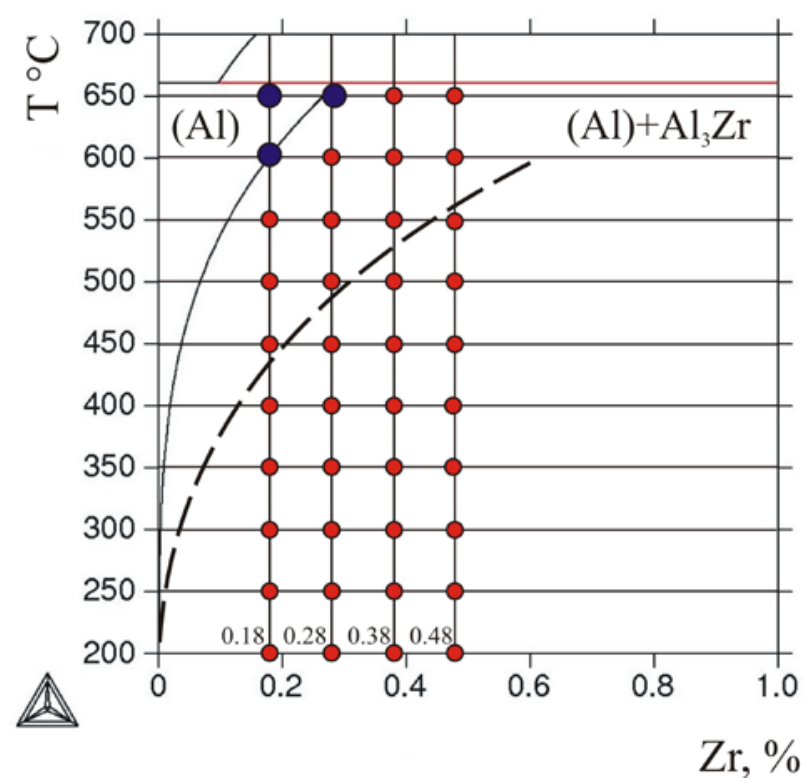

Fig. 6 


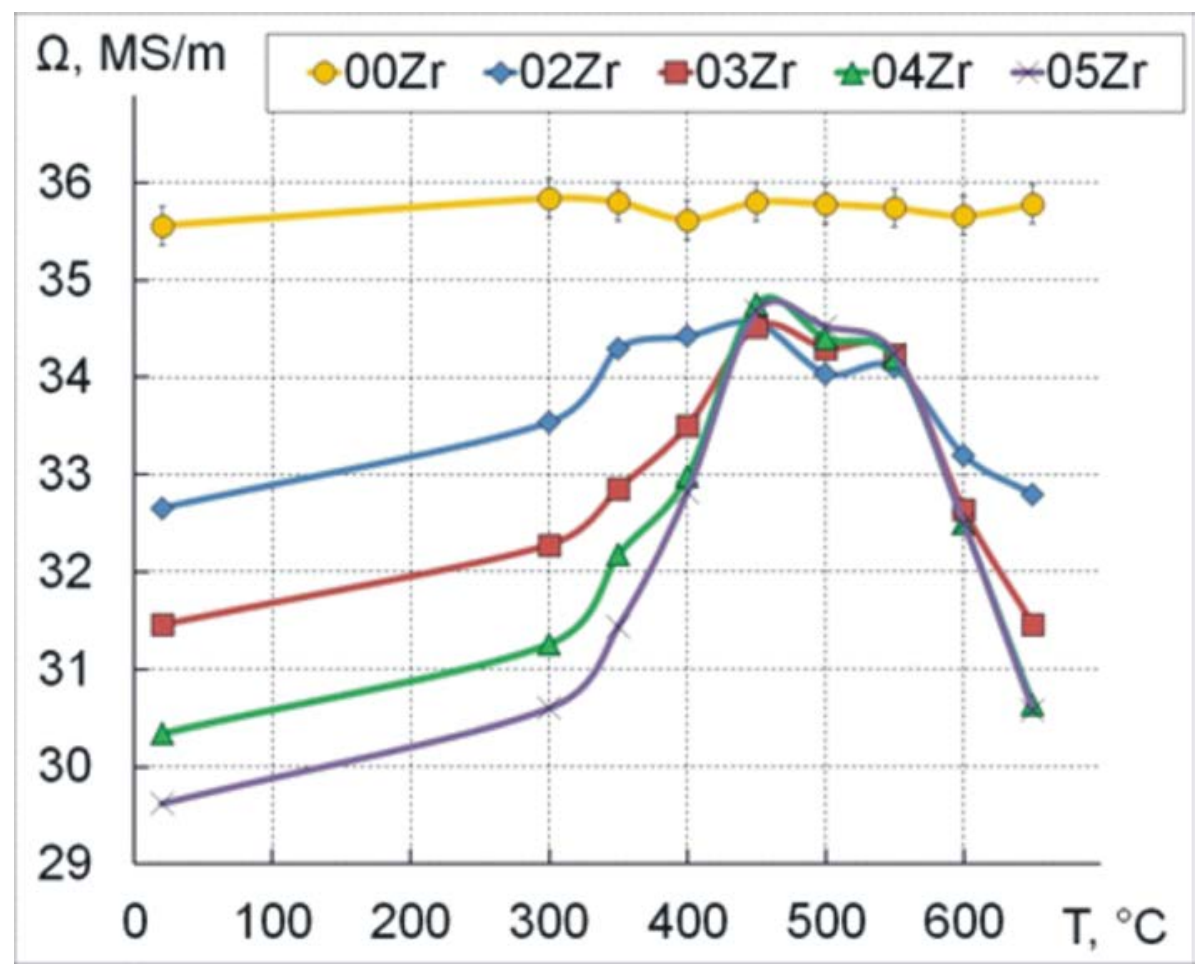

Fig. 7a

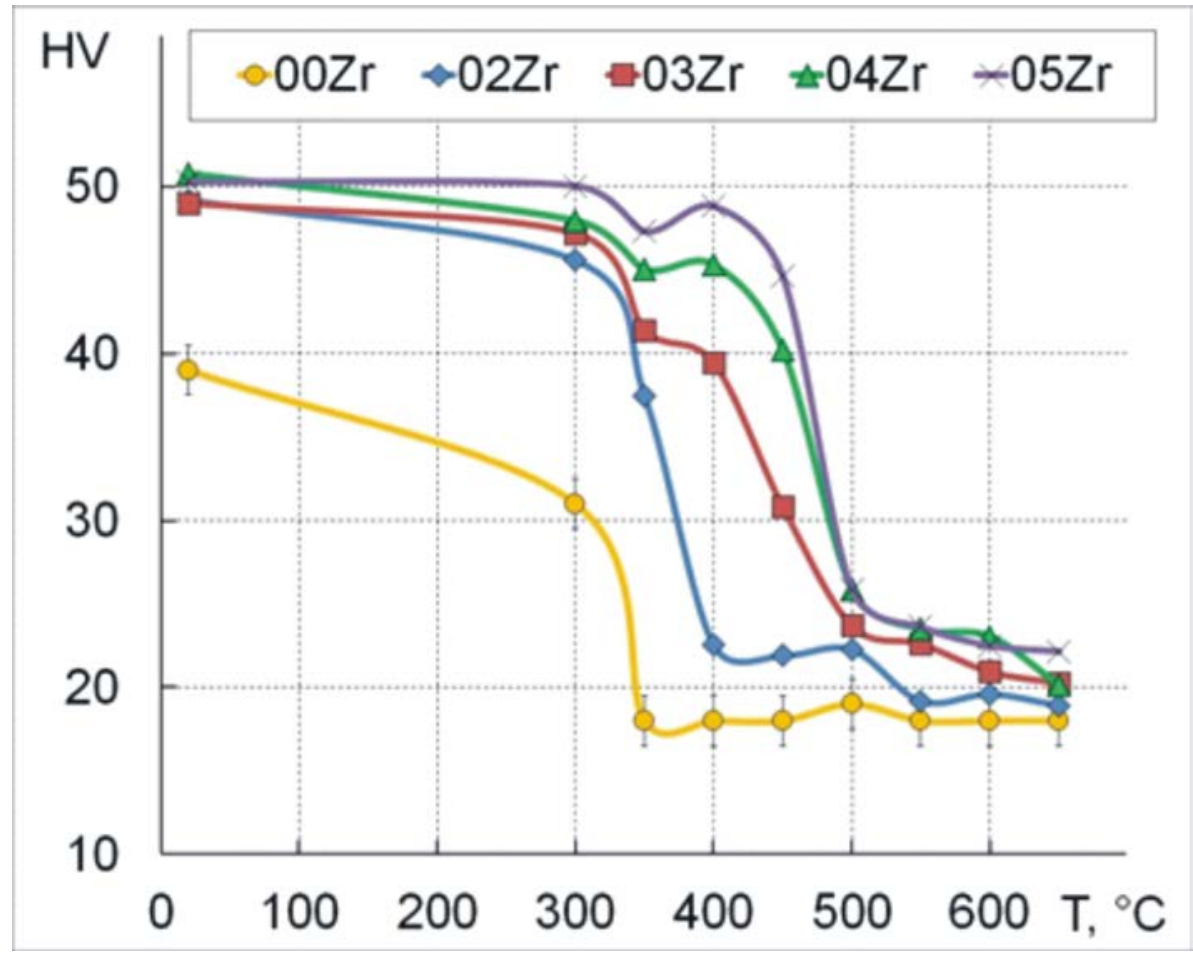

Fig. 7b 


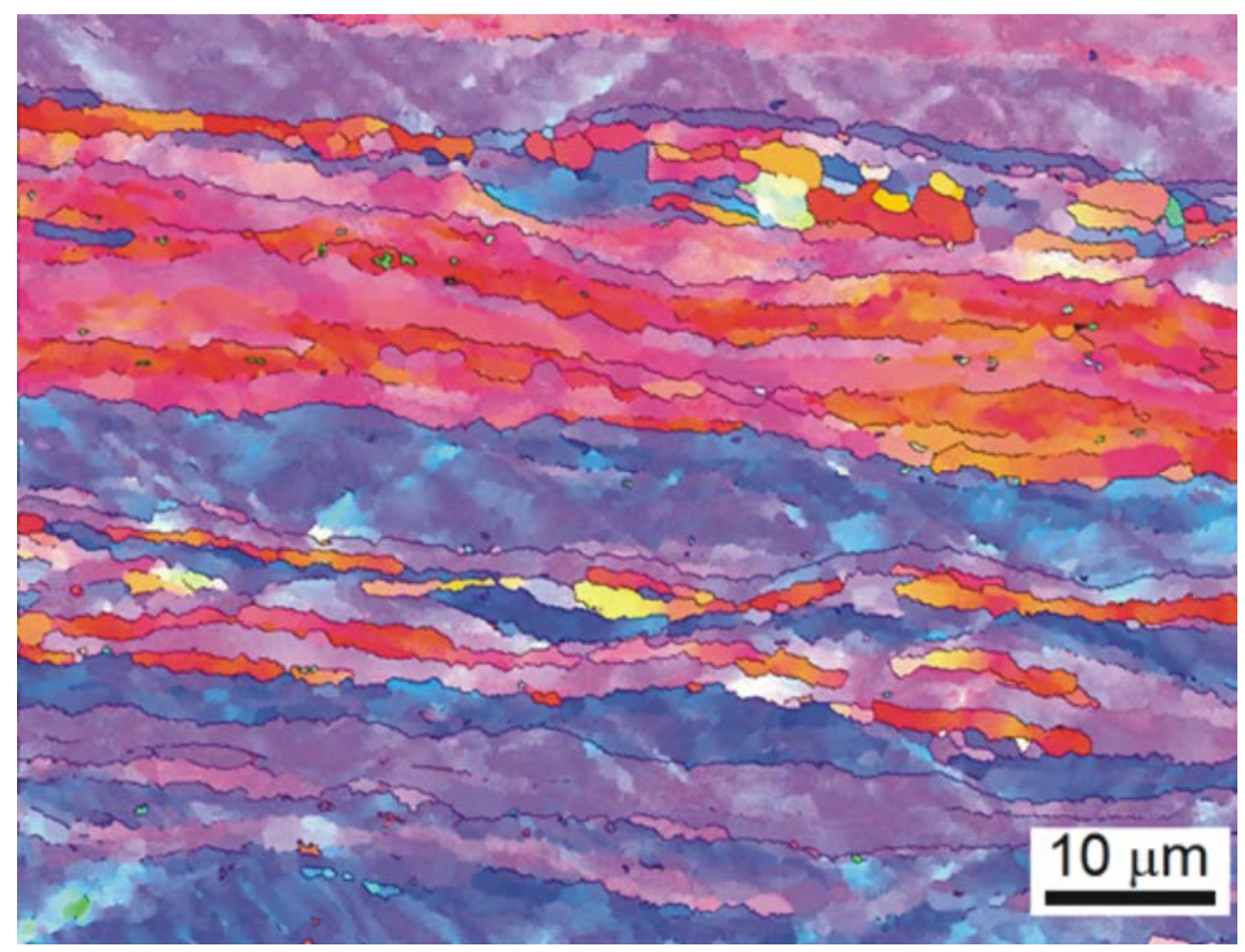

Fig. 8
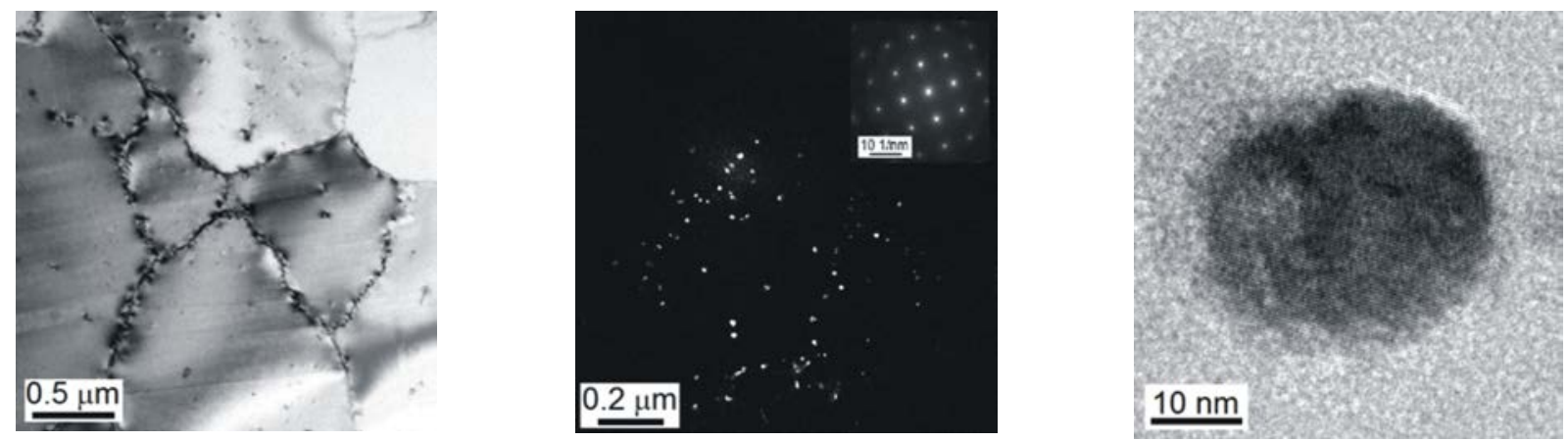

Fig. 9

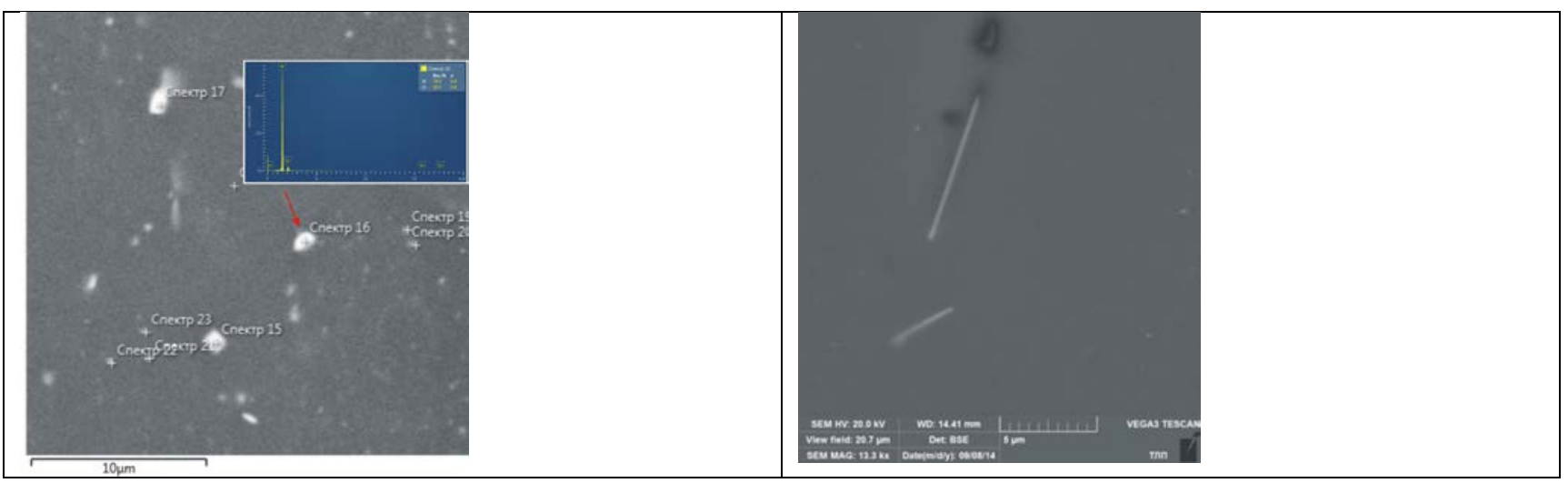

Fig. 10 


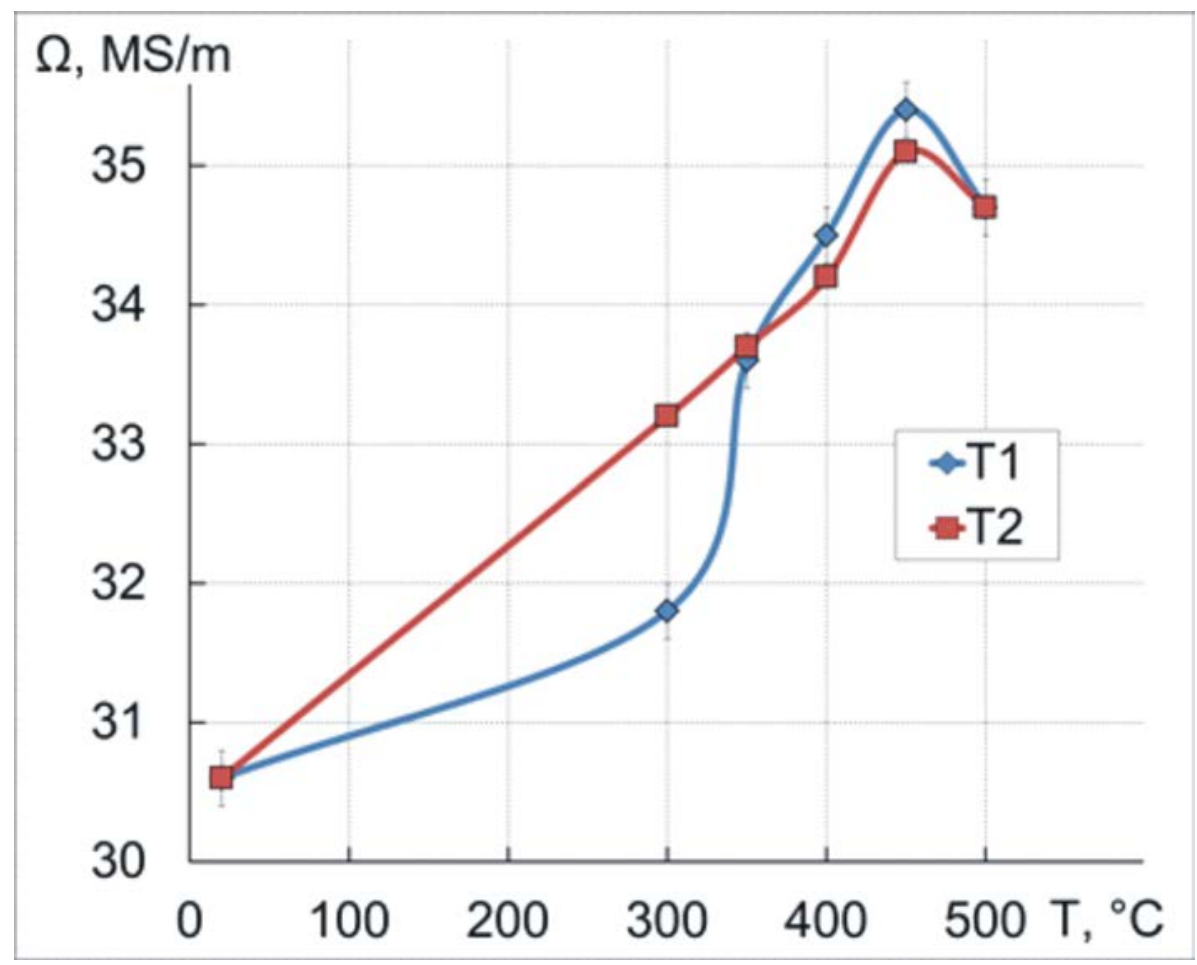

Fig. 11

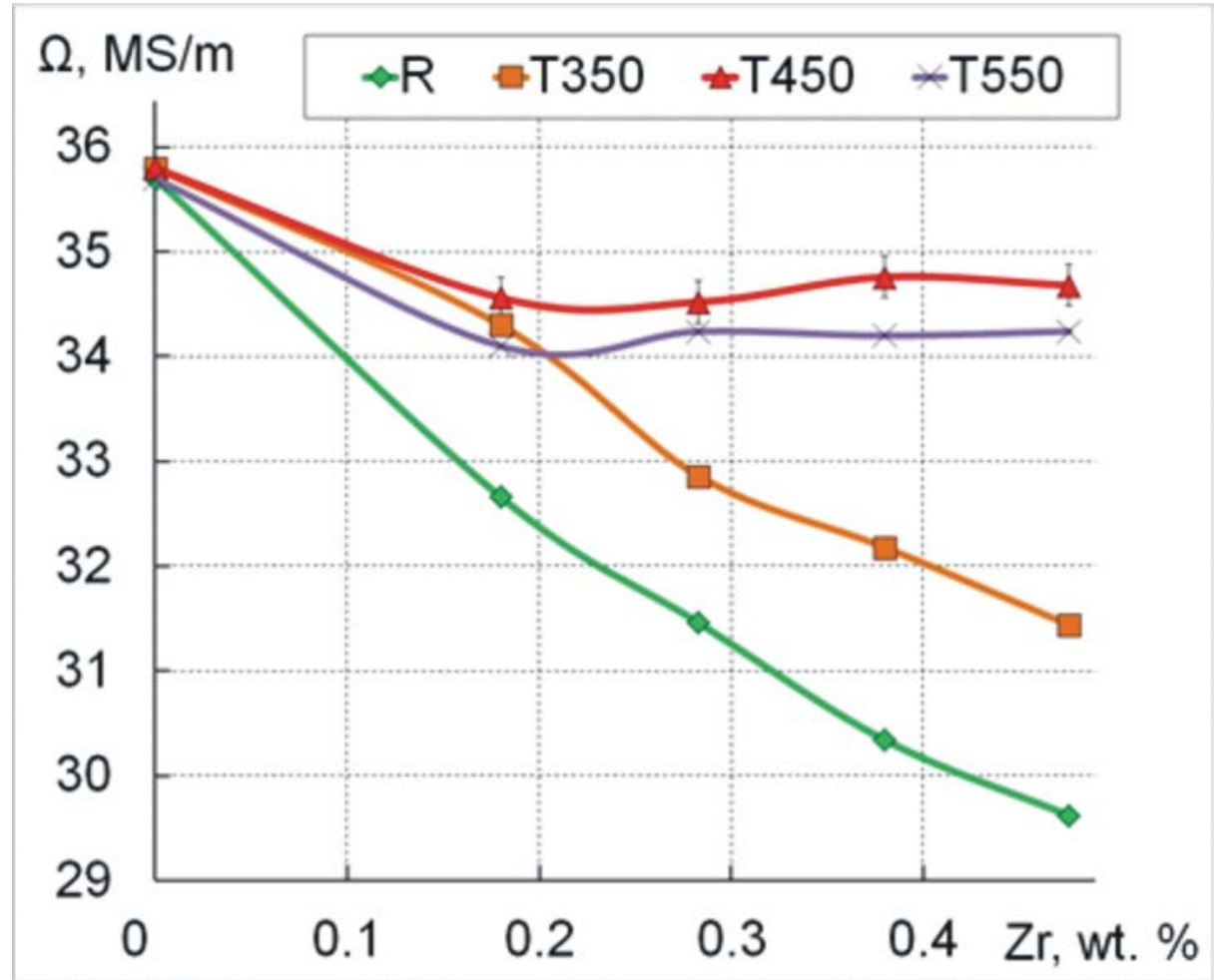

Fig. 12a 


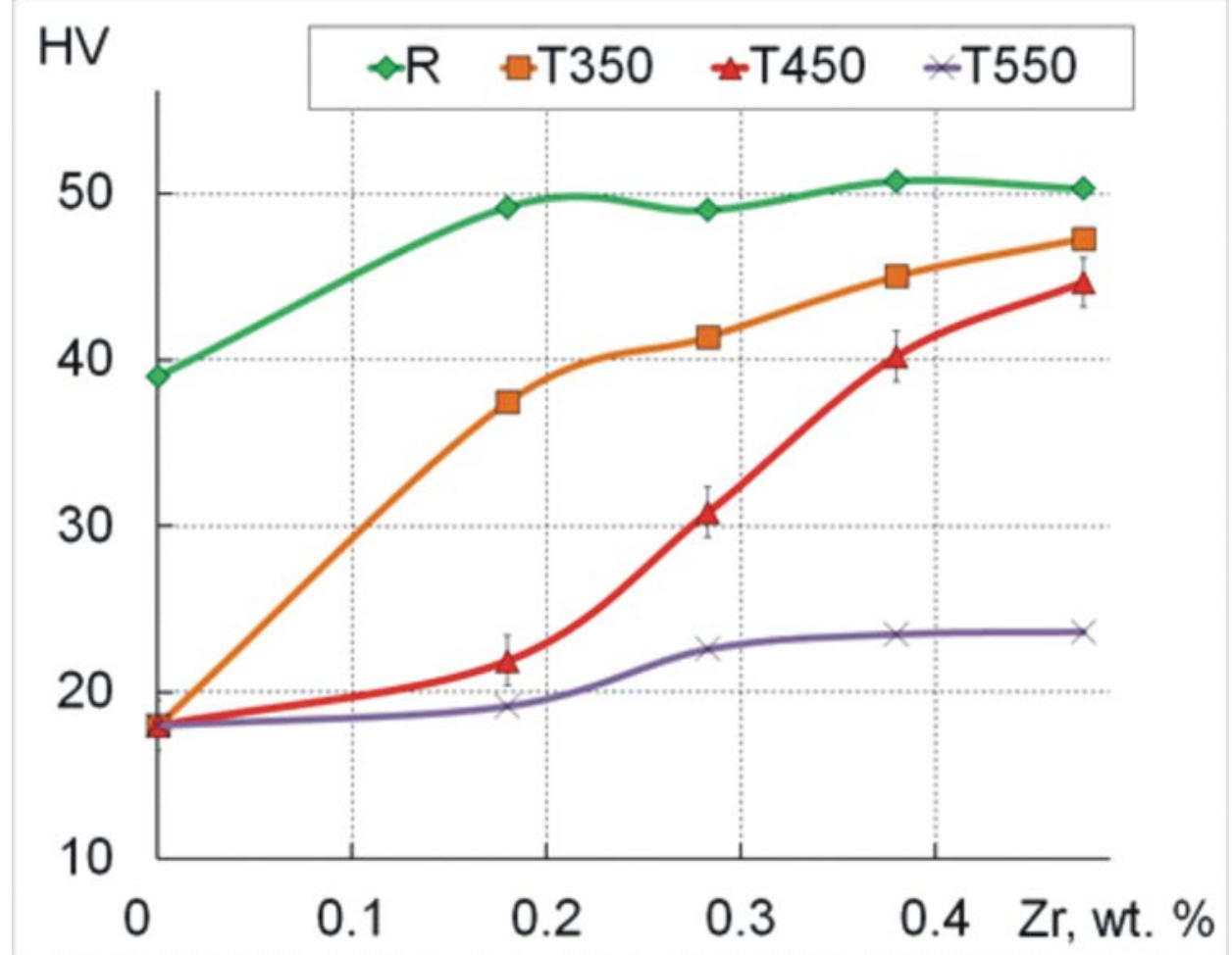

Fig. 12b 